\title{
Determining Optimum Rates of Mineral Fertilizers for Economic Rice Grain Yields under the "Sawah" System in Ghana
}

\author{
Buri Mohammed Moro*, Issaka Roland Nuhu' ${ }^{1}$ and Wakatsuki Toshiyuki ${ }^{2}$ \\ ${ }^{I}$ CSIR-Soil Research Institute, Academy Post Office, Kwadaso, Kumasi, Ghana \\ ${ }^{2}$ Faculty of Agriculture, Kinki University, Nara 631 - 8505, Japan \\ *Corresponding author
}

\begin{abstract}
Nutrient input and output balances are very essential for maintaining balances in not only soil nutrient management but also in preventing pollution and waste through excess use. A study was undertaken to determine the optimum levels of the major elements $(\mathrm{N}, \mathrm{P}, \mathrm{K})$ required for optimum lowland rice yields under the "sawah" system within the Biem and Dwinyan watersheds of the Ashanti Region, Ghana. Results show that the sites suffer multinutrient (N, P, K) deficiencies, with $\mathrm{N}$ and $\mathrm{P}$ being more pronounced. Mineral fertilizer positively and significantly affected rice paddy grain yield. The addition of $30 \mathrm{~kg} / \mathrm{ha}$ each of $\mathrm{N}, \mathrm{P}_{2} \mathrm{O}_{5}$ and $\mathrm{K}_{2} \mathrm{O}$ increased mean paddy grain yield by $71 \%, 51 \%$ and $56 \%$, respectively. The application of higher rates of $\mathrm{N}(>90 \mathrm{~kg} / \mathrm{ha}$ ) did not reflect in yield improvement and, therefore, was not economically beneficial. Optimum grain yield was observed at $60 \mathrm{~kg} \mathrm{P}_{2} \mathrm{O}_{5} / \mathrm{ha}$ and $60 \mathrm{~kg} \mathrm{~K}_{2} \mathrm{O} / \mathrm{ha}$. Site significantly affected grain yield only in the first year. Maximum economic grain yields were observed from the rates 90-60-90 and 90-90-60 kg/ha N - $\mathrm{P}_{2} \mathrm{O}_{5}-\mathrm{K}_{2} \mathrm{O}$, respectively. From the results obtained, 90-60-60 kg/ha N- $\mathrm{P}_{2} \mathrm{O}_{5}-\mathrm{K}_{2} \mathrm{O}$ is recommended for these areas.
\end{abstract}

\section{Introduction}

Over supply or under supply of plant nutrients can have negative consequences and, hence, result in the desired results being not obtained. The principle of balanced fertilization requires that this damaging effect be eliminated through the judicious use of fertilizers in order to sustain an economically viable and environmentally friendly agriculture that will meet the requirements of the future (Ernst \& Mutert, 1995). Despite recent efforts at encourag-ing/promoting increases in production, rice yields per unit area are still very low in Ghana (JICA/CSIR joint study project, 2001). Among identified causes for the low yields are declining soil fertility and the inability of farmers to use the required quantities of mineral fertilizers.

IFDC (1998) reported that annual rate of nutrient depletion from soils of Ghana between 1993-95 in $\mathrm{kg}$ of $\mathrm{N}+\mathrm{P}_{2} \mathrm{O}_{5}+\mathrm{K}_{2} \mathrm{O}$ per ha was 51-100 while the average annual rate of nutrients required to achieve optimum levels of crop production in $\mathrm{kg}$ of $\mathrm{N}+\mathrm{P}_{2} \mathrm{O}_{5}+\mathrm{K}_{2} \mathrm{O}$ per ha was greater than 80 . Rice growing environments of the West African sub-region have been reported to be not only low in inherent fertility but also actually very deficient in some major nutrients. (Buri \& Wakatsuki, 1996; Buri et al., 1998, 1999: Issaka et al., 1996ab, 1997; Windmeijer \& Andriesse, 1993; Andriesse et al., 1995).

Rice may benefit from the use of fertilizer to compensate exported nutrients. It is estimated that, for every one tone of rice grain harvested, about $15-20 \mathrm{~kg} \mathrm{~N}, 2-3 \mathrm{~kg} \mathrm{P}$ and $15-20 \mathrm{~kg} \mathrm{~K}$ is removed from the soil. With the introduction of new and high yielding rice varieties, soil nutrient mining will be on the increase when mineral fertilizer additions are absent or not in adequate amounts. Sarfo et al. (1998) noted that, for most crops, the best fertilizer type, rate and time of application are not known and that this constitutes a constraint to the use of fertilizer. They also noted that mineral fertilizers are not used because of their high cost, suggesting that lower rates of mineral fertilizers should be included in fertilizer trials because they may be more acceptable financially to producers. Also, the full cost of fertilizer handling (purchase, transport and application) should be used in a financial analysis. Finally, it should be determined whether any nutrients can be omitted from a productive fertilizer regime.

West African Journal of Applied Ecology, Vol. 12, 2008 
The "Sawah" system (bunded, levelled and puddled irrigated fields using simple water harvesting structures) was introduced to farmers within the study area. This study was, therefore, conducted to (i) evaluate the response of rice to mineral fertilization under the "sawah" systemlowland conditions, (ii) establish optimum levels of these nutrients required for obtaining maximum marginal rates of return on investment, and (iii) confirm that all nutrients $(\mathrm{N}, \mathrm{P}$ and $\mathrm{K}$ ) are required.

\section{Location of experimental sites}

\section{Materials and methods}

The experiments were conducted at two sites, Adugyama $\left(06^{\circ}, 53^{\prime} 07.8^{\prime \prime} \mathrm{N}\right.$ and $001^{\circ}, 52^{\prime} 40.1^{\prime \prime}$ $\mathrm{W})$ within the Dwinyan watershed and Biemso No. $1\left(06^{\circ}, 52^{\prime} 53.2^{\prime \prime} \mathrm{N}\right.$ and $\left.001^{\circ}, 50^{\prime} 47.3^{\prime \prime} \mathrm{W}\right)$ within the Biem watershed in 2004 and 2005.

Management practices

Land preparation. For each year and site, land was demarcated and cleared of vegetation. After the initial clearing, the sites were ploughed with a power tiller and demarcated into replications by bunding. Replicated plots were flooded, rotovated and puddled using a power tiller, and manually levelled using a wooden plank. Each replicate was then divided (use of smaller bunds) into smaller plots (treatments).

Transplanting. Transplanting was manually done at a square spacing of $20 \mathrm{~cm} \times 20 \mathrm{~cm}$ and at three seedlings per stand. Seedlings were transplanted at 25 days after nursing. Seedlings were transplanted in August of each year.

Fertilization. Mineral fertilizer at the various rates were applied using urea as $\mathrm{N}$ sources, triple super phosphate (TSP) as P source and muriate of potash (MoP) as K source. All P and K with $50 \% \mathrm{~N}$ was applied as basal fertilizer, a week after transplanting. The remaining $\mathrm{N}$ was applied as topdressing at panicle initiation stage. Each time, fertilizer was applied by broadcast.

Weed control. Weed control was mainly by water (maintaining a minimum water level of between 5-10 cm above soil surface). However, there was occasional handpicking of waterresistant weeds.

Harvesting. Harvesting was done manually in December of each year. For each site, an area of $2 \mathrm{~m}^{2}$ per treatment was used as the harvestable area. Rice was carefully cut using knives, threshed, winnowed and sun-dried to $14 \%$ moisture level. Grain weights were then taken. Based on such area, grain yield per hectare was estimated.

Laboratory analysis

Composite soil samples (0-15 and 15-30-cm depths) per site were collected after land clearing. Samples were air-dried, ground and passed through a 2-mm mesh sieve. Soil $p \mathrm{H}\left(\mathrm{H}_{2} \mathrm{O}\right)$ was determined using a $p \mathrm{H}$ meter (with a glass electrode) in a soil to water ratio of 1:2.5 (IITA, 1979). Organic carbon content was determined by the wet combustion method (IITA, 1979). Total nitrogen content was determined by the Macro-Kjeldahl method (IITA, 1979). Available P was determined by the Bray No. 2 method (IITA, 1979). Exchangeable cations were first extracted with ammonium acetate $\left(1.0 \mathrm{M} \mathrm{NH}_{4} \mathrm{OAc}\right)$. The contents of various cations in the extract were determined by atomic absorption spectro-photometry (IITA, 1979).

\section{Statistical analysis}

Yield data for the 2 years were analyzed. In each year, ANOVA of paddy grain yield was done for both sites combined and then for each site separately.

\section{Partial budget analysis}

West African Journal of Applied Ecology, Vol. 12, 2008 
A partial budget analysis was carried out for promising rates based on the CIMMYT (1988) approach. Total cost that vary (TCV) was calculated as the sum of the fertilizer purchase cost, the transport cost, and the application cost. Costs related to mineral fertilizer at the time of the experiment were urea, $\$ 51 / 100 \mathrm{~kg}$; triple super phosphates, $\$ 40 / 100 \mathrm{~kg}$; muriate of potash, $\$ 38 / 100 \mathrm{~kg}$; transport cost of fertilizer per $100 \mathrm{~kg}, \$ 2.2$; and cost of fertilizer application per 100 $\mathrm{kg}$ was $\$ 3$. The transport cost of fertilizer was estimated from market to field border/farm gate. The farm gate price of rice was assumed to be the retail price in village markets during the period. The analysis was done for the experiments conducted in 2005 using the mean yields of both sites combined.

Actual yield was adjusted to $70 \%$ of experimental yield to take into account higher plant population density, timely labour availability and better management (e.g. weed control, better security) under experimental conditions. Net benefits were calculated as the difference between gross benefits and the TCV. A dominance analysis was done after the partial budget analysis where dominated options were eliminated and the marginal rate of return (MRR) calculated for the remaining options. Exchange rate was one US dollar to nine thousand Ghanaian cedis (US\$1 $\approx ф 9000$ in 2005).

\section{Initial soil characteristics}

\section{Results}

Mean soil characteristics of the experimental sites (Adugyama and Biemso No. 1) for both years (2004 and 2005) are shown in Table 1. Biemso No. 1 soils were more acidic particularly the topsoil $(0-15 \mathrm{~cm})$. Organic matter and total $\mathrm{N}$ were quite lower at Biemso No. 1. Available P was very low for both sites. Exchangeable cations (K, Ca Mg, Na) were higher at Adugyama. Serious leaching of cations might have occurred at Biemso No. 1.

TABLE 1

Mean soil characteristics of the experimental sites for 2004 and 2005

\begin{tabular}{|c|c|c|c|c|}
\hline \multirow[b]{3}{*}{ Parameter } & \multicolumn{4}{|c|}{ Site } \\
\hline & \multicolumn{2}{|c|}{ Adugyama } & \multicolumn{2}{|c|}{ Biemso No. 1} \\
\hline & $0-15 \mathrm{~cm}$ & $15-30 \mathrm{~cm}$ & $0-15 \mathrm{~cm}$ & $15-30 \mathrm{~cm}$ \\
\hline$p \mathrm{H}$ & 6.1 & 6.2 & 5.1 & 5.7 \\
\hline Organic carbon $\left(\mathrm{g} \mathrm{kg}^{-1}\right)$ & 26.3 & 23.1 & 14.6 & 8.5 \\
\hline Total nitrogen $\left(\mathrm{g} \mathrm{kg}^{-1}\right)$ & 2.8 & 2.4 & 1.30 & 0.8 \\
\hline Available $\left.\mathrm{P}\left(\mathrm{mg} \mathrm{kg}^{-1}\right)\right)$ & 0.47 & 0.35 & 1.34 & 0.89 \\
\hline Exchangeable $\mathrm{K}\left\{\mathrm{cmol}(+) \mathrm{kg}^{-1}\right\}$ & 0.09 & 0.08 & 0.03 & 0.03 \\
\hline Exchangeable $\mathrm{Ca}\left\{\mathrm{cmol}(+) \mathrm{kg}^{-1}\right\}$ & 6.23 & 7.15 & 3.00 & 3.72 \\
\hline Exchangeable $\mathrm{Mg}\left\{\operatorname{cmol}(+) \mathrm{kg}^{-1}\right\}$ & 3.09 & 2.87 & 1.30 & 2.18 \\
\hline Exchangeable $\mathrm{Na} \quad\left\{\mathrm{cmol}(+) \mathrm{kg}^{-1}\right\}$ & 1.28 & 1.21 & 0.48 & 0.76 \\
\hline Exchangeable acidity $\left\{\operatorname{cmol}(+) \mathrm{kg}^{-1}\right\}$ & 0.05 & 0.05 & 0.43 & 0.13 \\
\hline Effective CEC $\left\{\mathrm{cmol}(+) \mathrm{kg}^{-1}\right\}$ & 10.74 & 11.36 & 5.24 & 6.82 \\
\hline Texture & Loam & Clay loam & Loam & Sandy clay loam \\
\hline
\end{tabular}

Soil type Eutric gleysol Eutric gleysol

\section{Missing nutrient effect}

The effect of not including N, P, or K on grain yield is shown in Table 2. In 2004 and at both sites, $\mathrm{N}$ and $\mathrm{P}$ were the most limiting. In 2005 all the three elements seriously influenced rice grain yield.

\section{TABLE 2}

West African Journal of Applied Ecology, Vol. 12, 2008 
Effect of the non-inclusion of a mineral nutrient on grain yield (t/ha)

\begin{tabular}{lcccc} 
& \multicolumn{2}{c}{ Adugyama } & \multicolumn{2}{c}{ Biemso No. 1 } \\
$\left(\mathrm{N}-\mathrm{P}_{2} \mathrm{O}_{5}-\mathrm{K}_{2} \mathrm{O}\right) \mathrm{kg} / \mathrm{ha}$ & 2004 & 2005 & 2004 & \\
& & & & 1.47 \\
$0-90-90$ & 1.29 & 1.48 & 1.39 & 2.04 \\
$90-0-90$ & 2.03 & 2.08 & 1.99 & 2.53 \\
$90-90-0$ & 3.09 & 2.31 & 7.75 & 7.11 \\
$90-90-90$ & 6.84 & 6.89 & &
\end{tabular}

Grain yield response to $N$

Mineral fertilizer effect on paddy grain yield is shown in Table 3. Mean grain yield for both years increased significantly with increasing $\mathrm{N}$ rates reaching a peak at $90 \mathrm{~kg} \mathrm{~N} / \mathrm{ha}$. The same trend was observed at both sites for the 2 years. Paddy grain yields without fertilizer $\mathrm{N}$ ranged from 1.29 to $1.39 \mathrm{t} / \mathrm{ha}$ in 2004 and from 1.47 to $1.48 \mathrm{t} / \mathrm{ha}$ in 2005 . The addition of $30 \mathrm{~kg} / \mathrm{ha} \mathrm{N}$ increased grain yield by $69 \%$ (2.98 t/ha) in 2004 and 67\% (2.94 t/ha) in 2005 . The mean increase was $68 \%$ (2.96 t/ha). $\mathrm{N}$ had significant effect on grain yield up to $90 \mathrm{~kg} / \mathrm{ha}$ after which the effect was not significant.

TABLE 3

Effect of increasing nitrogen $(N)$ levels on grain yield ( $t / h a)$ at the two sites

Treatment $\left(\mathrm{N}-\mathrm{P}_{2} \mathrm{O}_{5}-\mathrm{K}_{2} \mathrm{O}\right) \mathrm{kg} / \mathrm{ha}$
Adugyama

(a) 2004

$0-90-90-1.29$

30-90-90 4.27

$60-90-905.94$

$90-90-906.84$

120-90-90

$150-90-90$

LSD (0.05) fertilizer

Mean site 5.21

LSD (0.05) site

(b) 2005

$0-90-90 \quad 1.48$

$30-90-904.33$

60-90-90 6.04

90-90-90 6.89

$120-90-90$

$150-90-90$

LSD (0.05) fertilizer

Mean site 5.25

LSD (0.05) site
Site

Biemso No. $1 \quad$ Treatment mean

\begin{tabular}{|c|c|c|}
\hline 1.39 & 1.34 & \\
\hline 4.39 & 4.33 & \\
\hline 6.50 & 6.22 & \\
\hline 7.07 & 6.96 & \\
\hline 6.52 & 6.77 & 6.65 \\
\hline 6.42 & 6.47 & 6.45 \\
\hline 0.50 & 0.58 & 0.35 \\
\hline
\end{tabular}

$1.47 \quad 1.47$

$4.50 \quad 4.41$

$6.59 \quad 6.31$

$7.11-7.00$
6.64

$\begin{array}{lll}6.64 & 6.70 & 6.67\end{array}$

$\begin{array}{lll}6.50 & 6.47 & 6.48\end{array}$

$\begin{array}{lll}0.61 & 0.69 & 0.41\end{array}$

5.47

0.24

Grain yield response to $P$

In both years, mean grain yield increased significantly with increasing P levels to 60 $\mathrm{kg} / \mathrm{ha}$ and became similar thereafter. Paddy grain yields without fertilizer P ranged from 1.99 to $2.03 \mathrm{t} / \mathrm{ha}$ in 2004 and from 2.04 to $2.08 \mathrm{t} / \mathrm{ha}$ in 2005 (Table 4). Similarly, the addition of $30 \mathrm{~kg} / \mathrm{ha} \mathrm{P}_{2} \mathrm{O}_{5}$ increased grain yield by $51 \%(2.06 \mathrm{t} / \mathrm{ha})$ in 2004 and by the same margin $(2.11 \mathrm{t} / \mathrm{ha})$ in 2005.

TABLE 4

West African Journal of Applied Ecology, Vol. 12, 2008 
Effect of increasing phosphorus levels on grain yield (t/ha) at the two sites

\begin{tabular}{|c|c|c|c|}
\hline \multirow{2}{*}{$\begin{array}{c}\text { Treatment }\left(\mathrm{N}-\mathrm{P}_{2} \mathrm{O}_{5}-\mathrm{K}_{2} \mathrm{O}\right) \mathrm{kg} / \mathrm{ha} \\
\text { Adugyama }\end{array}$} & \multicolumn{2}{|c|}{ Site } & \\
\hline & Biemso No. 1 & Treatment mean & \\
\hline \multicolumn{4}{|l|}{ (a) 2004_ } \\
\hline $90-0-90-2.03$ & 1.99 & 2.01 & \\
\hline $90-30-904.08$ & 4.07 & 4.07 & \\
\hline $90-60-906.80$ & 6.99 & 6.96 & \\
\hline $90-90-906.84$ & 7.07 & 7.39 & \\
\hline $90-120-90$ & 6.79 & 6.72 & 6.76 \\
\hline LSD (0.05) fertilizer & 0.12 & 0.12 & 0.71 \\
\hline Mean (site) & 5.51 & 5.37 & \\
\hline LSD (0.05) site & \multicolumn{2}{|c|}{0.45} & \\
\hline \multicolumn{4}{|l|}{ (b) 2005} \\
\hline $90-0-90 \quad 2.08$ & 2.04 & 2.06 & \\
\hline $90-30-904.17$ & 4.17 & 4.17 & \\
\hline $90-60-90 \quad 8.23$ & 8.17 & 8.20 & \\
\hline $90-90-906.79$ & 7.11 & 6.95 & \\
\hline $90-120-90$ & 7.20 & 6.98 & 7.09 \\
\hline LSD (0.05) fertilizer & 0.17 & 0.12 & 0.92 \\
\hline Mean (site) & 5.70 & 5.70 & \\
\hline LSD (0.05) site & \multicolumn{2}{|c|}{0.58} & \\
\hline
\end{tabular}

\section{Grain yield response to $\mathrm{K}$}

A similar increasing trend in grain yield with increasing rates of $\mathrm{K}$ was also observed for both years and at both locations. Increase in grain yield peaked at $60 \mathrm{~kg} / \mathrm{ha} \mathrm{K}_{2} \mathrm{O}$ after which grain yield became similar. Paddy grain yields without fertilizer $\mathrm{K}$ ranged from 2.98 to $3.09 \mathrm{t} / \mathrm{ha}$ in 2004 and from 2.31 to $2.52 \mathrm{t} / \mathrm{ha}$ in 2005 (Table 5). The addition of $30 \mathrm{~kg} / \mathrm{ha} \mathrm{K}_{2} \mathrm{O}$ increased grain yield by $44 \%(2.27 \mathrm{t} / \mathrm{ha})$ in 2004 and $56 \%$ (3.10 t/ha) in 2005 . The mean increase was $50 \%(2.68$ $\mathrm{t} / \mathrm{ha})$. The mean yield increase from the second increment/level of fertilizer (30-60 kg/ha) for the three elements was also significantly higher than first increment $(0-30 \mathrm{~kg} / \mathrm{ha})$.

\section{TABLE 5}

Effect of increasing potassium $(K)$ levels on grain yield ( $t / h a)$ at the two sites

Treatment $\left(\mathrm{N}-\mathrm{P}_{2} \mathrm{O}_{5}-\mathrm{K}_{2} \mathrm{O}\right) \mathrm{kg} / \mathrm{ha}$ Adugyama

(a) 2004

90-90-0 3.09

90-90-30 5.24

90-90-60 6.71

90-90-90 6.84

LSD (0.05) fertilizer

Mean (site)

LSD (0.05) site

(b) 2005

90-90-0 2.31

90-90-30 5.40

90-90-60 7.82

90-90-90 6.79

LSD (0.05) fertilizer

Mean (site)

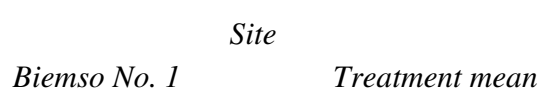

Biemso No. $1 \quad$ Treatment mean

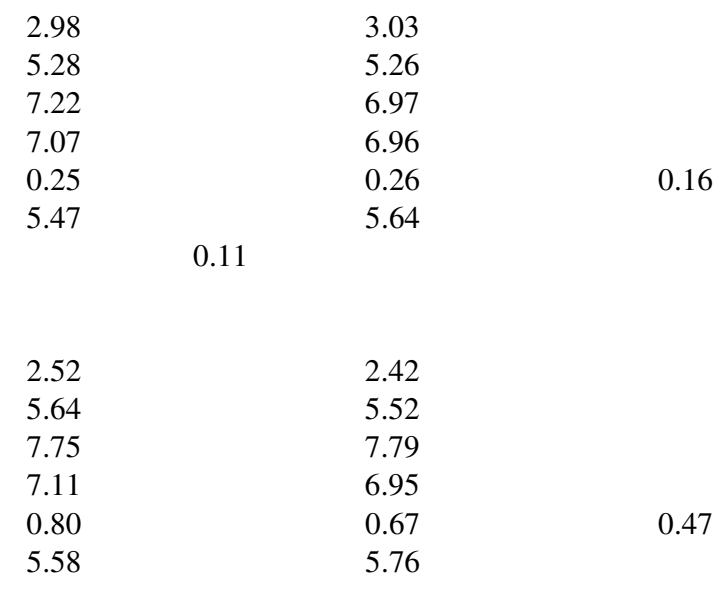

West African Journal of Applied Ecology, Vol. 12, 2008 


\section{General grain yield response}

In 2004, grain yield response to fertilizer attained peak values at $6.96,7.01$ and $7.39 \mathrm{t} / \mathrm{ha}$ grain yield corresponding to fertilizer rates of 90-90-90, 90-90-60 and 90-60-90 kg/ha N-P $\mathrm{O}_{5}-\mathrm{K}_{2} \mathrm{O}$, respectively (Table 6). In 2005, grain yield response to fertilizer attained peak values of 7.04, 7.79 and $8.20 \mathrm{t} / \mathrm{ha}$ corresponding to the same fertilizer rates of 90-90-90, 90-90-60 and 90-60-90 $\mathrm{kg} / \mathrm{ha} \mathrm{N}-\mathrm{P}_{2} \mathrm{O}_{5}-\mathrm{K}_{2} \mathrm{O}$, respectively. The ANOVA for the two sites combined in 2004 and 2005 showed the effect of fertilizer rates to be highly significant on grain yield. While the effect of location was only significantly different in 2004, fertilizers $\times$ location interactions were nonsignificant for both years. Paddy grain yields without fertilizer ranged from $0.96 \mathrm{t} / \mathrm{ha}$ in 2004 to $1.10 \mathrm{t} / \mathrm{ha}$ in 2005 .

TABLE 6

Effect of mineral fertilizer on paddy grain yield ( $t / h a)$ at the two sites

\begin{tabular}{|c|c|c|c|}
\hline Treatment $\left(\mathrm{N}-\mathrm{P}_{2} \mathrm{O}_{5}-\mathrm{K}_{2} \mathrm{O}\right) \mathrm{kg} / \mathrm{ha}$ & \multicolumn{2}{|c|}{ Site } & \\
\hline Adugyama & Biemso No. 1 & Treatment mean & \\
\hline \multicolumn{4}{|l|}{ (a) 2004} \\
\hline $0-0-0 \quad 0.96$ & 0.97 & 0.97 & \\
\hline $0-90-90 \quad 1.29$ & 1.39 & 1.34 & \\
\hline $30-90-904.27$ & 4.39 & 4.32 & \\
\hline $60-90-905.94$ & 6.50 & 6.22 & \\
\hline $90-90-906.84$ & 7.07 & 6.96 & \\
\hline $120-90-90$ & 6.52 & 6.77 & 6.65 \\
\hline $150-90-90$ & 6.42 & 6.47 & 6.45 \\
\hline $90-0-90 \quad 2.03$ & 1.99 & 2.01 & \\
\hline $90-30-904.08$ & 4.07 & 4.07 & \\
\hline $90-60-907.80$ & 6.99 & 7.39 & \\
\hline $90-120-90$ & 6.79 & 6.72 & 6.76 \\
\hline $90-90-0 \quad 3.09$ & 2.75 & 2.92 & \\
\hline $90-90-305.24$ & 5.13 & 5.19 & \\
\hline $90-90-606.71$ & 7.31 & 7.01 & \\
\hline LSD (0.05) fertilizer & 0.74 & 0.83 & 0.53 \\
\hline Mean (site) & 4.86 & 4.90 & \\
\hline LSD (0.05) site & & & \\
\hline \multicolumn{4}{|l|}{ (b) 2005} \\
\hline $0-0-0 \quad 1.06$ & 1.10 & 1.07 & \\
\hline $0-90-90 \quad 1.48$ & 1.47 & 1.47 & \\
\hline $30-90-904.33$ & 4.50 & 4.41 & \\
\hline $60-90-906.04$ & 6.59 & 6.31 & \\
\hline $90-90-906.89$ & 7.11 & 7.04 & \\
\hline $120-90-90$ & 6.64 & 6.70 & 6.64 \\
\hline $150-90-90$ & 6.65 & 6.47 & 6.47 \\
\hline $90-0-90 \quad 2.08$ & 2.04 & 2.06 & \\
\hline $90-30-904.17$ & 4.17 & 4.17 & \\
\hline $90-60-908.23$ & 8.17 & 8.20 & \\
\hline $90-120-90$ & 7.20 & 6.98 & 7.09 \\
\hline $90-90-0 \quad 2.31$ & 2.53 & 2.42 & \\
\hline $90-90-305.40$ & 5.64 & 5.52 & \\
\hline $90-90-607.82$ & 7.75 & 7.79 & \\
\hline
\end{tabular}


LSD (0.05) fertilizer

Mean (site)

$\operatorname{LSD}(0.05)$ site 0.25 $\begin{array}{ll}0.11 & 0.83 \\ 5.01 & 5.09\end{array}$
0.67

Fertilizer effect on some growth com-ponents

The effect of fertilizer rate on some growth components are shown in Table 7 and Fig. 1 and 2. The addition of the first $30 \mathrm{~kg} / \mathrm{ha} \mathrm{N}$ resulted in significant increases in tiller number at both sites for both years (Table 7). Increasing $\mathrm{N}$ rates above $90 \mathrm{~kg} / \mathrm{ha}$ also resulted in significant increases in plant height (Fig. 1) for both years at both sites. However, this only resulted in higher biomass production with no corresponding increase in grain yield, thus, reflecting lower harvest indices (HI) for treatments with higher rates of $\mathrm{N}$ (Fig. 2). The highest harvest indices were observed at $90 \mathrm{~kg} / \mathrm{ha} \mathrm{N}$ and between 60 to $90 \mathrm{~kg} / \mathrm{ha}$ each of $\mathrm{P}_{2} \mathrm{O}_{5}$ and $\mathrm{K}_{2} \mathrm{O}$.

TABLE 7

Effect of mineral fertilizer on tiller number at the two sites

Treatment $\left(\mathrm{N}-\mathrm{P}_{2} \mathrm{O}_{5}-\mathrm{K}_{2} \mathrm{O}\right) \mathrm{kg} / \mathrm{ha}$ Adugyama

(a) 2004

$0-0-0 \quad 7.4$

$0-90-90 \quad 8.5$

$30-90-9012.8$

$60-90-9013.6$

90-90-90 14.8

120-90-90

150-90-90

$90-0-90 \quad 13.1$

90-30-90 13.8

90-60-90 12.7

90-120-90

90-90-0 12.5

90-90-30 12.9

90-90-60 14.3

LSD (0.05) fertilizer

Mean (site)

LSD (0.05) site

(b) 2005

$0-0-0 \quad 9.5$

$0-90-90 \quad 9.8$

30-90-90 14.8

60-90-90 15.2

90-90-90 14.8

120-90-90

150-90-90

90-0-90 15.1

90-30-90 15.8

90-60-90 14.7

$90-120-90$

90-90-0 14.8

90-90-30 14.9

90-90-60 16.3

LSD (0.05) fertilizer

Mean (site)

LSD (0.05) site 0.84

Site

$$
\text { Biemso No. } 1 \quad \text { Treatment mean }
$$

7.5

9.5

15.2

16.2

16.4

13.8

15.0

14.4

14.9

11.6

13.9

13.1

13.8

14.8

2.05

12.8

10.5

11.3

18.6

19.2

15.4

15.8

17.0

16.4

17.0

14.5

15.9

16.0

15.6

17.4

2.05

14.6
7.4

9.0

14.0

14.9

15.6

15.3

13.8

13.8

14.4

12.1

12.8

12.8

13.4

14.5

2.05

13.5

0.96

14.6

14.4

13.3

2.00

15.9

16.9

15.7

16.4

14.6

16.1

15.2

15.8

16.9

2.06

15.8
16.0

2.00

West African Journal of Applied Ecology, Vol. 12, 2008 

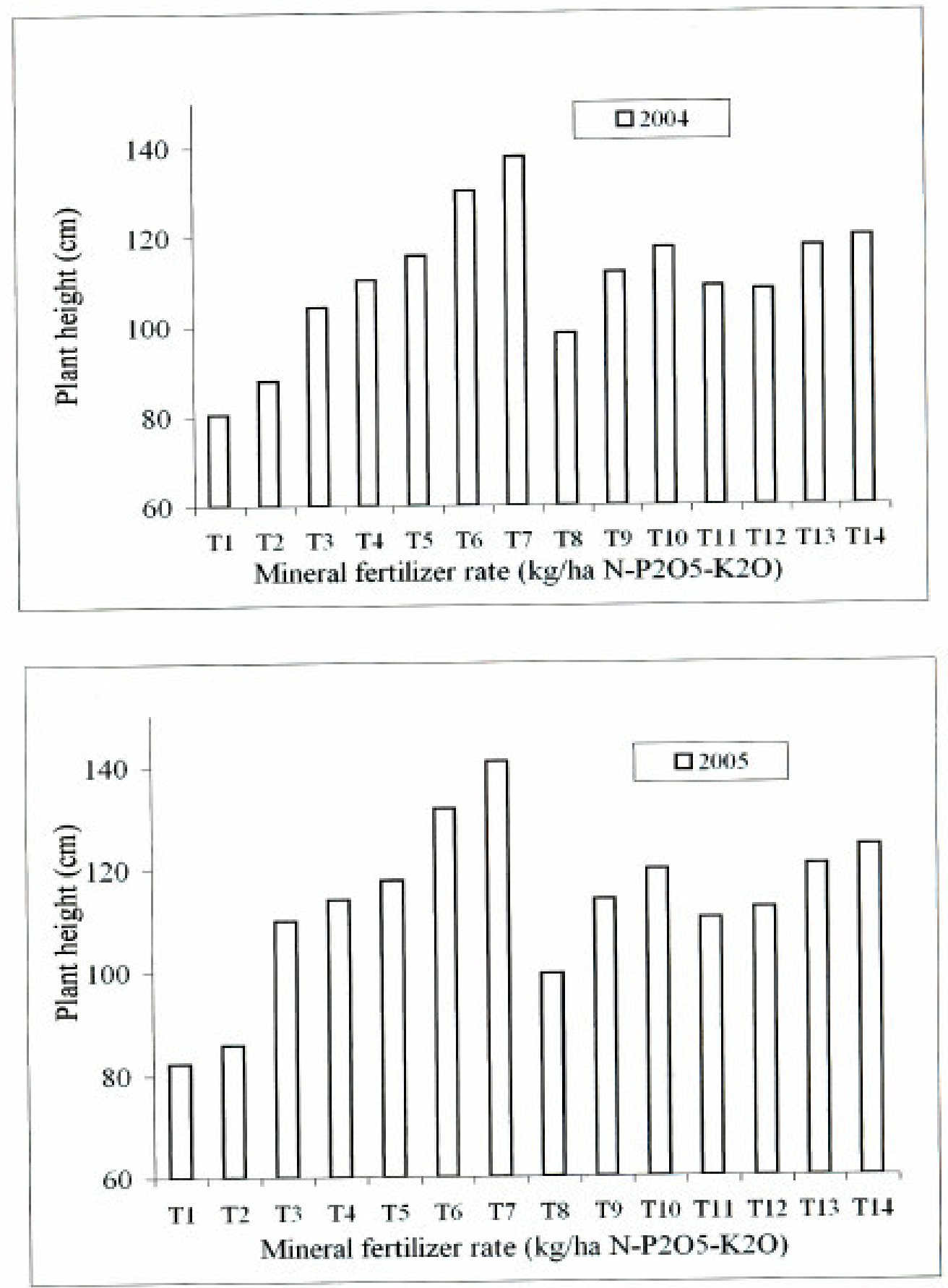

$\mathrm{T} 1=0-0-0 ; \mathrm{T} 2=0-90-90 ; \mathrm{T} 3=30-90-90 ; \mathrm{T} 4=60-90-90 ; \mathrm{T} 5=90-90-90 ;$

$\mathrm{T} 6=120-90-90 ; \mathrm{T} 7=150-90-90 ; \mathrm{T} 8=90-0-90 ; \mathrm{T} 9=90-30-90 ; \mathrm{T} 10=90-60-90$ $\mathrm{T} 11=90-120-90 ; \mathrm{T} 12=90-90-0 ; \mathrm{T} 13=90-90-30 ; \mathrm{T} 14=90-90-60$.

Fig. 1. Effect of mineral fertilizer on plant height 


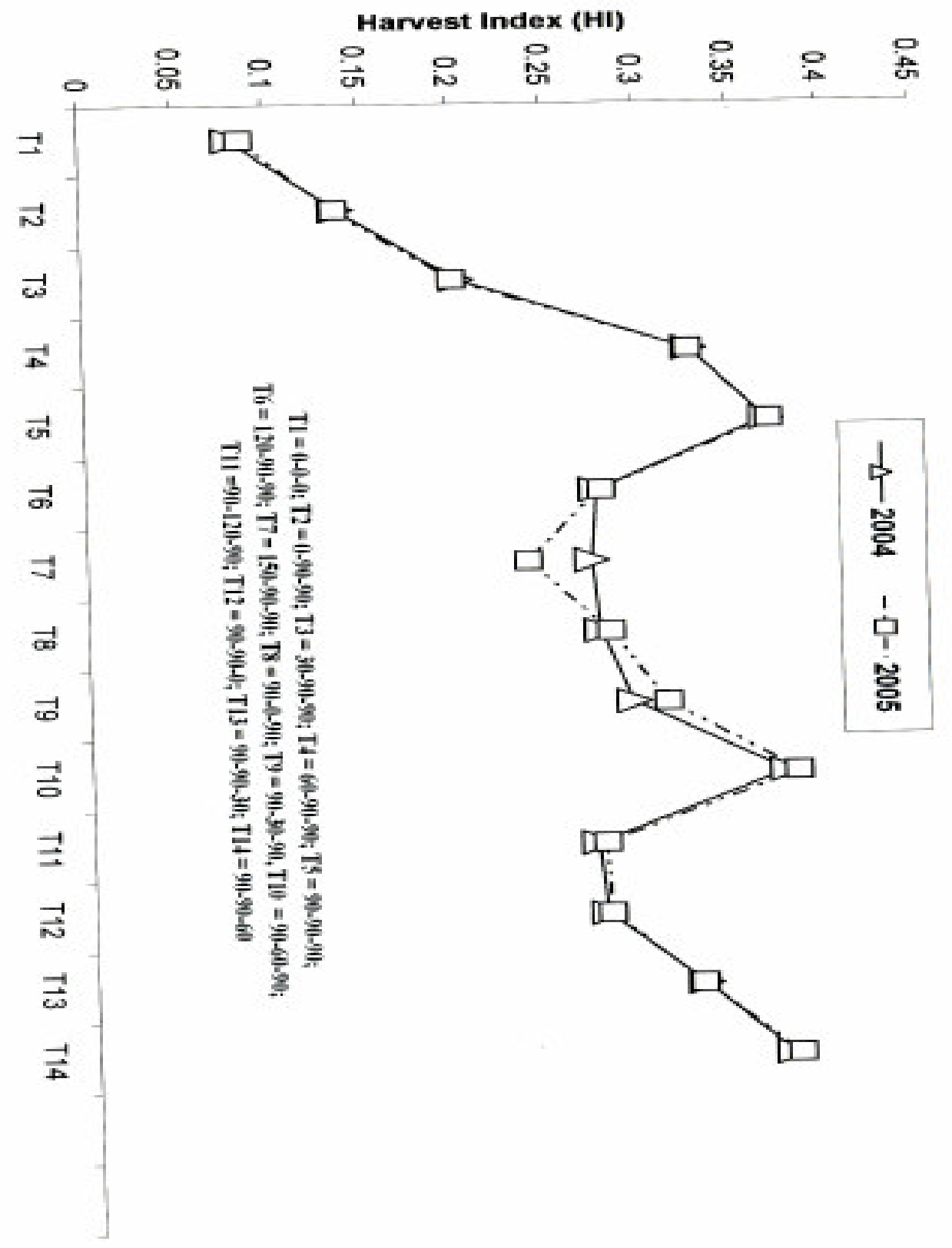

Fig. 2. Effect of mineral fertilizer on harvest index (HI)

\section{Partial budget}

The total cost that varies (TCV) was $\$ 116.58 /$ ha for the $90-60-90$ treatment and 117.18 for the 90-90-60 treatment (Table 8a). Mineral fertilizer rates beyond 90-90-60 kg/ha N, $\mathrm{P}_{2} \mathrm{O}_{5}, \mathrm{~K}_{2} \mathrm{O}$ resulted in lower net revenue and were, therefore, dominated by the first increment of fertilizer (Table 8b). Highest net revenue was obtained when mineral fertilizer was applied at 90-60-90 $\mathrm{kg} / \mathrm{ha} \mathrm{N}, \mathrm{P}_{2} \mathrm{O}_{5}, \mathrm{~K}_{2} \mathrm{O}$. This was followed by $90-90-60 \mathrm{~kg} / \mathrm{ha} \mathrm{N}, \mathrm{P}_{2} \mathrm{O}_{5}, \mathrm{~K}_{2} \mathrm{O}$. The marginal rate of return (MRR) was highest (14) for the mineral fertilizer rate, 90-60-90 kg/ha N, $\mathrm{P}_{2} \mathrm{O}_{5}, \mathrm{~K}_{2} \mathrm{O}$. Reduction of 90-90-60 to 90-60-60 and 90-60-90 to 90-60-60 due to the results shown in Tables 4 and 5 will further increase profit. 
TABLE 8a

Estimates of costs that vary $(\$ / h a)$ from applying different combinations of mineral fertilizer $(N, P, K)$ to rice in 2005

$\begin{array}{lcccccc}\mathrm{N}-\mathrm{P}_{2} \mathrm{O}_{5}-\mathrm{K}_{2} \mathrm{O}(\mathrm{kg} / \mathrm{ha}) & \begin{array}{c}\text { Urea } \\ (\$)\end{array} & \begin{array}{c}\mathrm{TSP} \\ (\$)\end{array} & \begin{array}{c}\text { MoP } \\ (\$)\end{array} & \begin{array}{c}\text { Transport } \\ (\$)\end{array} & \begin{array}{c}\text { Application } \\ (\$)\end{array} & \begin{array}{c}\text { Total variable } \\ \text { costs }(\$)\end{array} \\ 0-0-0 & & & & & & \\ 90-60-90 & 0 & 0 & 0 & 0 & 0 & 0 \\ 90-90-60 & 45.9 & 24 & 34.2 & 5.28 & 7.20 & 116.58 \\ 90-90-90 & 45.9 & 36 & 22.8 & 5.28 & 7.20 & 117.18 \\ & 45.9 & 36 & 34.2 & 5.94 & 8.10 & 130.14\end{array}$

Fertilizer prices: $100 \mathrm{~kg}$ urea $=\$ 51 ; 100 \mathrm{~kg}$ TSP $=\$ 40 ; 100 \mathrm{~kg} \mathrm{MoP}=\$ 38$. Fertilizer transport cost $=\$ 2.2 / 100 \mathrm{~kg}$; Application cost $=\$ 3 / 100 \mathrm{~kg}$.

TABLE $8 \mathrm{~b}$

Estimates of gross and net revenue (\$/ha) from applying different combinations of mineral fertilizer $(N, P, K)$ for rice in 2005

\begin{tabular}{|c|c|c|c|c|c|c|c|}
\hline$N-P$ & Adjuste & Gro & & $T C V$ & Net revenue & Dominance & \\
\hline$(\mathrm{kg} / \mathrm{ha})$ & yield ( $\mathrm{kg} / \mathrm{ha})$ & $(\$)$ & $(\$)$ & & $(\$)$ & & \\
\hline $0-0-0$ & 749 & 262.15 & 0 & & 262.15 & & \\
\hline $90-60-90$ & 5740 & 2009 & 116.58 & & 1892.42 & & 14 \\
\hline $90-90-60$ & 5453 & 1908.55 & 117.18 & & 1791.37 & $\mathrm{D}$ & \\
\hline $90-90-90$ & 4928 & 1724.80 & 130.14 & & 1594.66 & $\mathrm{D}$ & \\
\hline
\end{tabular}

Price $/ 100 \mathrm{~kg}$ paddy $=\$ 35$. Adjusted yield $=70 \%$ of mean yield (Table $6 \mathrm{~b}$ ).

Missing nutrient effect

\section{Discussion}

Where one or two nutrients are found to be limiting yield, it may be justified to apply single element fertilizers or to change the formula of compound fertilizers to better reflect the needs of the crop. The importance of $\mathrm{N}$ in determining yield increases has been reported by several authors (Obigbesan, 1981). In the first year (2004), N and P were the most limiting nutrients at both sites. All the three elements (N,P,K) showed the same degree of limitation at both sites in the second year (Table 2). Soil test levels of $>0.2 \mathrm{cmol} / \mathrm{kg}$ soil $\mathrm{K}$ and $>9-10$ p.p.m. P may not respond to $\mathrm{P}$ and K fertilization (Doberman \& Fairhurst, 1999). Soil test results of the site show K and P levels to be far below these critical levels. It is clear that at both sites, N, P, K all limit rice production. The results show that $\mathrm{N}$ application was justified in both 2004 and 2005 and at both sites because yield losses were significant without this nutrient. In both years, the absence of $\mathrm{N}$ significantly reduced yields at the two sites (Adugyama and Biemso No. 1).

For both locations combined, the mean yield loss from withholding $\mathrm{N}$ was $2.94 \mathrm{t} / \mathrm{ha}$ in 2005 . For the two trials combined (2004 and 2005), yield loss due to withholding $N$ (5.93 t/ha) was significant at $P<0.001$. Thomas et al. (2001) indicated that $\mathrm{P}$ fertilization increased average grain yield by $20 \%$, total biomass by $27 \%$ and $\mathrm{P}$ uptake by $53 \%$ in upland rice in the Philippines. In this study, a similar observation was made as $\mathrm{P}$ fertilization resulted in higher increases in grain yield under lowland conditions. Seasonal potassium uptake pattern of flooded-irrigated rice characterized on $\mathrm{K}$ sufficient soils, indicated that adequate $\mathrm{K}$ must be present during vegetative growth to maximise K uptake (Slaton et al., 2003). In this study, the relatively low levels of K makes it more necessary for the application of $\mathrm{K}$ if optimum yields are to be obtained. This is much reflected in the highly significant increases in grain yield when $\mathrm{K}$ was applied. 
Response to increasing rates of $N, P, K$

Increasing $\mathrm{N}$ rates $(>90 \mathrm{~kg} / \mathrm{ha}$ ) only resulted in increases in plant height and total biomass (Fig. 1 and 2). Higher $\mathrm{N}$ rates stimulate tillering and formation of new leaves, causing shading, a condition that favours diseases, lodging and reductions in productivity. Even though no diseases were observed in this study, lodging was very severe in higher $\mathrm{N}$ rates. $\mathrm{N}$ fertilizer was generally beneficial and clear with increasing rates up to $90 \mathrm{~kg} / \mathrm{ha}$ before flattening off. Witt et al. (2004) indicated that site specific nutrient management approach to rice provided sufficient robust estimates of long term fertilizer $\mathrm{P}$ and $\mathrm{K}$ requirements to avoid nutrient depletion. They further added that long term experiments may be required to fine-tune fertilizer $\mathrm{P}$ and $\mathrm{K}$ recommendations developed on-farm. The same authors further stated that management of soil $\mathrm{P}$ and $\mathrm{K}$ is receiving greater attention in intensive irrigated lowland rice systems of Asia because of concerns that fertilizer $\mathrm{P}$ and $\mathrm{K}$ rates are not optimally adjusted to long term needs.

In Ghana, a similar case may arise as both $\mathrm{P}$ and $\mathrm{K}$ fertilization are given less attention. Instead, too much emphasis is laid on $\mathrm{N}$ fertilization leading to the use of mostly only $\mathrm{N}$ containing fertilizers. From this study, response to both $\mathrm{P}$ and $\mathrm{K}$ were quite clear and should provide a useful basis for the various quantities required. Yamaguchi (1989) observed that increases in $\mathrm{Fe}$ and decreases in $\mathrm{K}$ concentrations were prominent in bronzing of rice in Nigeria and suggested that proper fertilization and planting of resistant varieties may be the most suitable approach. Potassium is predo-minant in rice straw and straw management can greatly affect $\mathrm{K}$ availability and, consequently, quantities of it required as mineral additions. Improvements in rice straw management may, therefore, lead to reductions in the amount of $\mathrm{K}$ additions through mineral fertilizers.

\section{Conclusion}

From the initial soil properties and missing nutrient analysis, soils of both the Biem and Dwinyan watershed have been found to suffer from multi-nutrient deficiency, with $\mathrm{N}$ and $\mathrm{P}$ deficiencies being more pronounced. Responses to N, P, or K clearly show $90 \mathrm{kgN} / \mathrm{ha}, 60 \mathrm{~kg} \mathrm{P} \mathrm{O}_{5} / \mathrm{ha}$ and 60 $\mathrm{kg} \mathrm{K}_{2} \mathrm{O} / \mathrm{ha}$ as the optimum rates. The partial budget analysis shows that the application of 90-6090 or $90-90-60 \mathrm{~kg} / \mathrm{ha}$ of $\mathrm{N}-\mathrm{P}_{2} \mathrm{O}_{5}-\mathrm{K}_{2} \mathrm{O}$ had positive marginal rates of return and are, therefore, good options for farmers within the experiment's domain. Using a fertilizer rate of 90-60-60 will further increase profits. From the observations, site only had a significant effect on grain yield in the first year.

\section{Acknowledgement}

The Kinki University, Nara-Japan, to which the authors are very grateful, financially supported this research. The authors wish to thank all technical staff of the Soil Fertility \& Plant Nutrition and Laboratory Analytical Services divisions of the CSIR-Soil Research Institute, for effectively assisting in the conduct of the field work and soil sample analysis.

\section{References}

Andriesse W., Windmeijer P. N. and Van Duivenbooden N. (1995). Classifying Inland Valley Agro-ecosystems: A Modular Approach. In Proceedings of the 3rd Annual Workshop of the Inland Valley Consortium, WARDA, Cote d'Ivoire. pp. 47-62.

Buri M. M., Masunaga T., Ishida F., Kubota D. and Wakatsuki T. (1998). Soils of flood plains in West Africa: General fertility status. Soil Sci. Pl. Nutr. 45: 37-50.

Buri M. M., Masunaga T. and Wakatsuki T. (1999). Sulfur and zinc as limiting factors to rice production in West Africa lowlands. Geoderma 94: 23-42.

Buri M. M. and Wakatsuki T. (1996). Soils of flood plains in West Africa: Geographical and regional distribution of some fertility parameters. In Proceedings of the International Symposium on Maximizing Sustainable Rice Yields through Improved Soil and Environmental Management. Khon Kaen, Thailand. 1: 445-455.

West African Journal of Applied Ecology, Vol. 12, 2008 
CIMMYT (1988). From Agronomic Data to Farmer Recommendations. An Economic Training Manual, Completely revised edition. CIMMYT, Mexico. D.F. 79 pp.

Doberman A. and Fairhurst T. (1999). Field Handbook. Nutritional Disorders and Nutrient Management in Rice. IRRI. PPI/PPIC.

Ernst W. and Mutert E. (1995): Plant Nutrient Balances in the Asian and Pacific Region - The Consequences for Agricultural Production. In Food and Fertilizer Development Centre 2005. An International Information Centre for farmers in the Asia-Pacific region, Taiwan R. O. C.

IFDC (1998). Soil Nutrient Depletion. In Report of the Sub-Committee on Fertilizer Use for the National Agricultural Research Project (NARP), Ghana. (E. Y Sarfo and E. A. Dennis, ed.).

IITA (1979). Selected Methods for Soil and Plant Analysis. Manual Series No. 1. IITA, Ibadan, Nigeria.

Issaka R. N., Ishida F., Kubota D. and Wakatsuki T. (1997). Geographical distribution of selected soil parameters of inland valleys in West Africa. Geoderma 75: 99-116.

Issaka R. N., Masunaga T., Kosaki T. and Wakatsuki, T. (1996a). Soils of Inland Valleys of West Africa: General fertility parameters. Soil Sci. Pl. Nutr. 42: 71-80

Issaka R. N., Masunaga T. and Wakatsuki T. (1996b). Soils of Inland Valleys of West Africa: Geographical Distribution of Selected Soil Fertility Parameters. Soil Sci. Pl. Nutr. 42: 197-201.

JICA/CSIR Joint Study Project (2001). Final Report of JICA/CSIR Joint Study Project on Integrated Watershed Management of Inland Valleys in Ghana and West Africa: Eco-technology Approach. Sept. 2001. (T. Wakatsuki, E. Otoo, W. E. I. Andah, J. Cobbina, M. M. Buri and D. Kubota, ed.).

Obigbesan G. O. (1981). Nutrient Requirements of Yams (Dioscorea species). Agric. Res. Bull. 2(1). Faculty of Agriculture and Forestry, University of Ibadan, Ibadan, Nigeria. p. 20.

Sarfo E. Y., Ofori F. and Dennis E. A. (1998). Report of the Sub-Committee on Fertilizer Use for the National Agricultural Research Programme (NARP), Accra, Ghana.

Slaton N. A., Dunn D. and Pugh B. (2003). Potassium Nutrition of Flooded-Irrigated Rice. Bett. Crops. 88(3).

Thomas G., Roger M., Walter R., Koen V. K., Guy T and Veronica R. (2001). Upland Rice Response to Phosphorus Fertilization in Asia. Agron. J. 93: 1362-1370.

Windmeijer P. N. and Andriesse, W. (1993). Inland Valleys in West Africa: An Agro-Ecological Characterization of Rice-growing Environment. pp 28-37. ILRI, Wageningen, The Netherlands.

Witt C., Doberman R. B., Abdulrachman S., Gines H. C., Nagarajan R., Ramanathan S., Tan P. S. and Wang G. H. (2004). Long Term Phosphorus and Potassium Strategies in Irrigated Rice. Bett. Crops. 88(4).

Yamauchi M. (1989). Rice bronzing in Nigeria caused by nutrient imbalances and its control by potassium sulphate application. Pl. Soils 117: 275-286. Kluwer Academic Publishers. Netherlands.

West African Journal of Applied Ecology, Vol. 12, 2008 